ONE HUNDRED AND THIRTY-SECOND SCIENTIFIC MEETING

FIFTY-EIGHTH SCOTTISH MEETING

HANNAH DAIRY RESEARCH INSTITUTE, KIRKHILL, AYR

30 APRIL 1960

MINOR ELEMENTS IN NUTRITION

\author{
Chairman: Dr D. P. CUTHBERTSON, C.B.E., LL.D., F.R.S.E., \\ Rowett Research Institute, Bucksburn, Aberdeen
}

\title{
Minor elements in nutrition: Ghairman's opening remarks
}

\author{
By D. P. Cuthbertson, Rowett Research Institute, Bucksburn, Aberdeen
}

During the last 30 years a steadily increasing number of elements has been found to be constantly present in higher-plant and animal tissues. To those long known to be in greatest abundance--the so-called 'major elements'-definite biological functions have been assigned, but of those present in traces-the so-called 'minor elements'-definite biological roles can only be ascribed to some. That the number of minor elements known to be essential is small could be simply a reflection of the extraordinarily low concentrations involved which impose great technical difficulties. It seems probable that, as more highly purified media for plants or more highly purified and apparently nutritionally adequate diets for animals are developed and as physiological and analytical techniques improve, some at least of these 'accidental' minor elements will be found to have essential physiological functions in the tissues.

Certain plants have the faculty of assimilating considerable amounts of certain elements out of proportion to their abundance in the soil. Such plants are the socalled 'accumulators'. Others like Heliotropium europeum, containing hepatotoxic alkaloids, induce liver damage and excess storage of copper in the reduced number of remaining liver cells; the copper so stored is readily released to produce the haemolytic crisis characteristic of the disease. Animals require traces of iodine and cobalt and these they obtain mainly from plants, yet it has not been conclusively proved that these elements are essential for higher plants generally. On the other hand, the element boron is essential to plants but not, as far as is known, to animals. The luxuriance of a pasture species is not necessarily a criterion that its mineral content will contain all that is required for the grazing animal, and the usual commercial fertilizers may or may not add to a deficient soil what is missing.

A minor element, in the sense of our Symposium today on animal requirements, is generally a metal belonging to the transitional group of the periodic table-iodine, fluorine and selenium being exceptions-and which is present normally in the organism in not more than I part in 20000 (50 p.p.m.), and there subserves an essential function, most probably in some form of enzyme system, hormone or vitamin. Under the term 'minor element' we may group iron, cobalt, copper, molybdenum, manganese, zinc, iodine, possibly fluorine and selenium.

Iron is not usually regarded as a minor element because, although it occurs in the body to the extent of I part in 25000 , in the blood it is present to the extent of I in 
2000 and there acts as an oxygen carrier rather than as a catalyst. It is probably the only one to which we can assign a net requirement. For the others, requirements have to be expressed in terms of the amount in the feed, that is as $\mathrm{mg} / \mathrm{kg}$ dry matter.

Arnon's three tests of essentiality of an element for plants are (I) the life-cycle cannot be completed if it is absent, (2) its action must be specific and not replaceable by that of another element, (3) its effect on the plant must be direct. I think that these same criteria should be applied to tests of essentiality for animals. The difficulty lies in the application of such tests to higher animals.

\section{Trace elements in Scottish soils}

\section{By R. L. Mitchell, The Macaulay Institute for Soil Research, Craigiebuckler, Aberdeen}

Realization of the importance of certain trace elements in animal nutrition has led to a requirement for maps or other means of ascertaining the probable trace-element status of the soils of any locality. The more important factors which ultimately determine the amount of any trace element supplied to the grazing animal through the herbage are: (I) the total content in the soil and in the parent material from which the soil was derived, (2) the proportion of the total content capable of being utilized by the plant and (3) the relative uptakes of the various herbage species concerned.

In regions with extensive areas of soils derived from a fairly uniform parent material, such as the great continental plains, the trace-element status of the soil can often, as pointed out by Vinogradov (1959), be related directly to pedological factors and be readily mapped on small-scale maps, but in Scotland conditions are somewhat different, and such generalizations are impossible. Scotland is an area of complex geology, in which the parent rocks contain very variable amounts of the trace elements of biological importance, and the factor of primary importance is generally the soil parent material, although local soil conditions cannot be disregarded. In addition to igneous rocks of all types from ultrabasic to acidic, there occur arenaceous and argillaceous sedimentary rocks and limestones as well as metamorphic rocks of both igneous and sedimentary origin, sometimes in relatively small exposures. To complicate the picture further, several periods of glaciation have produced a surface drift, from which the soils have developed. This drift may have been transported some distance and may indeed be a mixture of several rock types rather than a derivative of the existing underlying rock.

\section{Trace elements in soil parent materials}

Before considering the distribution of the biologically important trace elements in Scottish soils, it is necessary to look briefly at the factors controlling their occurrence in rocks. The igneous rocks, from which both sedimentary and metamorphic 